\title{
The role of collaboration municipality - regional university in sustainable tourism development: Case study of Dagda county
}

\author{
Irena Silinevica \\ Rezeknes Augstskola, Faculty of Economics and Management. \\ Address: Atbrivosanas aleja 115, Rezekne. LV-4601,Latvia
}

\begin{abstract}
Research of different studies related to collaboration municipality - university allows to establish a fact that it is very important for both partners and has distinctive forms. The core questions of this research are as follows: Is the regional university significant player in regional sustainable tourism development? What forms of collaboration among regional university and municipality are possible? The aim of this research is to examine the experience of regional university in sustainable tourism development in regional area. This research is performed on the illustration of collaboration among regional university (Rezeknes Augstskola ) and Dagda county, which is one of the 19-th rural county in Latgale region. A new approach to the collaboration municipality - regional university is offered taking into account the possibilities of regional university in improvement of human resources capacity, in improvement of municipality administrative capacity, and in development of sustainable tourism products. The offered approach was set up by taking into account the interests of all stakeholders in this area.
\end{abstract}

Keywords: sustainable tourism, collaboration, municipality, university.

\section{INTRODUCTION}

The Latgale planning region (Latvia) includes 19 counties. Each of them has developed own Development programme, which includes an strategical part (further- Strategy). The strategical directions of the county development are defined in its Strategy. Each county of Latgale region forseens 'Tourism development' as one of the strategical direction. Tourism is the most environmentally friendly industry. This direction is based on picturesque environment with many lakes, rivers, and forests, rich culture and historical resources, e.t.c. In spite of this the main resources for tourism development are human resources, which are capable to transform tourism resources in attractive and sustainable tourism products. Kamalanabhant,T.,and Nagaraj,I. [1] underlined, that human capital is a relevant source of economic growth. Human resources should have the valuable distinctive competencies with aim to create a competitive advantage. The major challenges for the tourism business were defined by Cooper et.al [2]: the challenges facing the tourism industry will only be met successfully by a welleducated, well-trained, bright, energetic, multi-lingual and enterpreneurial workforce who understand the nature of tourism and have professional training. A high quality of professional human resources in tourism will allow to gain a competitive edge and deliver added value with their service.

By the Municipality Law the each municipality is responsible for improvement of business environment into its territory. Improvement of business environment is extended to the tourism business environment as well. There are many aspects of tourism sustainability like the municipality policy related to protection and maintanance of tourism resources, the attitude of local inhabitents to tourism development [4] and their willingness to take part in this process, e.t.c.. This study includes exclusively one aspect: opportunities of collaboration among municipality and regional university for tourism sustainable development in the territory of the county.

The aim of this study is to analyse the role of regional university in sustainable tourism development in regional area by use the illustration of collaboration among regional university (Rezeknes Augstskola (further - RA)) and Dagda county, which is one of the 19-th rural county in Latgale.

The 'Nature tourism development' as the strategical direction is defined in the Strategy of Dagda county[3].

To achieve this aim several objectives are defined:

- to interpret the theoretical aspects related to collaboration municipality - university; 
- to examine the experience of regional university in sustainable tourism development of the county;

- to create a new approach to development of the sustainable tourism offer in regional area by use collaboration opportunities among municipality and university;

- to develop conclusions about collaboration opportunities among municipality and university.

Research object: Collaboration municipality regional university.

Research subject: Factors, which influence on sustainable tourism development by use collaboration among municipality and regional university. Hypothesis of this research: It is possible to promote sustainable tourism by use the collaboration opportunities of municipality - university. This collaboration recovers new creative potential in tourism development and provides its sustainability.

To obtain the objectives of this study the following research methods were used: content analyses, analysis and synthesis, logical and abstract constructive methods.

Research base - Dagda county.

\section{THE THEORETICAL ASPECTS OF COLLABORATION AMONG MUNICIPALITY AND UNIVERSITY}

Nowadays the cooperation among universities and municipalities takes part in many countries in different forms. Thus for instance Linkoping municipality (Sweden) 'sees universities, colleges and other educational institutions as key partners for the development of its own activities, for community development as well as business growth in the municipality and the region. Having a successful university within its community also brings with it the challenge of offering an open and proactive municipal organisation that can exploit the results of research and education.' [5]. Linkoping municipality has developed Strategy for cooperation with universities and colleges. There are three fundamental reasons for collaboration with universities, colleges and other educational institutions defined in this strategy [5].

1) The municipality needs the skills, resources and results that come with the university in order to improve and develop its operations. If the municipality is to offer its citizens the best possible service, it requires competence that is based on recognized expertise, proven experience and the latest knowledge in science. Collaboration with the university is also important for Linköping so that it may strengthen the development and growth of the municipality as well as the region.
2) Close cooperation with universities is vital from an employment and growth perspective. Proximity in particular to Linköping University and its research resources, benefits not least the establishment of knowledge-intensive businesses and activities but also contributes to the establishment of more service operations. Therefore the university supports the municipality's aims to develop a broader business and labour market for greater economic sustainability, increased range of choices as well as contributing towards greater development dynamics.

3) Growth in the number of students in Linköping and in the region also increases the municipality's skills and recruitment base thus contributing positively to the municipality's potential for a positive population growth. The possibility to recruit foreign students also provides opportunities for wider international exchange with access to a larger range of goods, to the services market as well as increased resources for research. Attractive job opportunities, a rich cultural life and ample leisure activities are also important factors for universities if they are to attract staff and students.

The main tasks defined in this Strategy [5] are as follows.

1. The municipality should play a leading role in creating good cooperation with universities and colleges, with particular emphasis on interaction with the students.

2. The municipality should support the establishment and growth of research and development environments that are of importance for the municipality, the business sector and local residents.

3. The municipality should collaborate with universities and colleges within those areas that promote the municipality and its residents as well as the local and regional business community. The municipality will also support entrepreneurship and new enterprises originating from universities and colleges.

4. The municipality should take advantage of the universities and colleges as a resource for the organisation of the municipality ensuring development is based on recognized research and proven experience. The municipality's various departments are to collaborate with universities and colleges in the fields of research and development.

5. The municipality should provide attractive environments in which to live; social and community services that attract students and researchers to establish in the community. 
Postma,J [6] examined the cooperation of Twente university (Netherland) with local municipality in social sector. Reseacher noted that small municipalities are advised to pick the form that best suits their needs. Postma,J [6] defined the criteria which allow to most effectivily realise collaboration with universities in social sector. They are as followings: trust, number of participants, goal consensus and need for network - level competencies:

Abrahamson and Fairchild [7] have passed an opinion that 'academics may be losing out to other members of the fashion setting community, such as consultants and gurus, in terms of their ability to influence practice.'

Birkenshaw, Hamel and Mol [8] suggested to 'academics to become more creative in the development of new ideas and thought experiments that organizations might put into practice'. They had offered the form of cooperation such as innovation laboratory of London Business Schools' MLab, where researchers and practitioners come together to develop new practices in partnership.

Lennart Nilson,Mickael Planasch [9] noted, that 'cooperation universities - municipalities is less common than with companies and industries. Cities take up students for Project work less often probably because they are also(local) authorities. Industries may use $15 \%$ of the budget for development of products and research. Cities use close $0 \%$ ! The most important issues for cities are: waste, energy improvement, investments, economic restructuring, identity and cultural belonging, integration and poor neighborhoods.' These issues are defined in the Project on sustainable city development in the Baltic sea region 1999-2007 consisted of 30 cities, 15 universities, 9 countries

Lennart Nilson,Mickael Planasch [10] had defined the advantages of municipality - regional university cooperation for the students, for the company/municipality, and for the university. They are as follows.

For the students:

- many of the thesis Project lead to employment,

- the student does not need to take study loan during thesis,

- opportunity to find out if they would want to work at the company.

For the company/municipality:

- gets a valuable/competent help to get a problem solved or job done that they would not have resources for;

- chance to test a potential new employee;

- competence development.

For the university:

- pedagogic advantages;

- research posibilities;

- competence development.
The Sami university College as well as UiT/The Arctic University of Norway successfuly colloborate with municipalities of Avjuvarri Indigenious region. These universities has developed new study programmes and other training programmes with focus on Sami language and culture as potential sustainable sources for new businesses based on traditional Sami culture [10]

International cooperation among municipalities and universities has significant role because of obtaining new cognitions, experience and knowledge. Thus Rezekne (Latvia) city council [11] entered the public organization „Union of the Baltic Cities”in 1994. In cooperation among Rezekne city Council, Rezeknes Augstskola, and Kalmar municipality (Sweden) the Tourism Commission was set and managed by representatives of both municipalities.

The collaboration municipality - university allows to get new contacts, to implement of municipal work into real life that is based on knowledge, and opportunity to apply for international projects. Thus the main objectives of the Operational Programme IPA Slovenia-Croatia 2007 - 2013 project 'Living, lived revived cultural heritage" [12] were as follows:

- to support the preservation and revitalization of cultural heritage and thus strengthen the identity;

- to strengthen and develop the knowledge and capacities for heritage preservation, revitalization, and presentation;

- to support the inclusion of cultural heritage among assets for the development of the cross border area.

The added value of this Project was in a higher rate of integrating common material and non-material cultural heritage into the sustainable tourist offer, in new tourim products and in the promotion of the entire cross border area as a tourist destination in new forms and with an improved offer and a better use of natural and cultural resourses, which will ensure new sources of income for the rural areas. There will also be a possibility for the local population to participate in cultural and tourist activities.

The municipality/university(Greece, Romania, Bulgary) collaboration work : Interreg IVC2011 project „Innovative and responsible tourism territories" [13] promotes creation of innovative tourism products linked to the endogenous resources as a fundamental principle of responsible and sustainable tourism.

\section{III EXAMINATION THE EXPERIENCE OF COLLABORATION AMONG DAGDDA COUNTY AND REGIONAL UNIVERSITY (RA) IN DEVELOPMENT OF SUSTAINABLE TOURISM}

Dagda county Development Programme 2013.2019 [3].indicates that one of the Programme's 
priority is Improvement and Diversification of Tourism products. Programme does not forsee improvement of county's competitiveness by Human resources management, related to people who are involved in Tourism development process [4].

The Action plan of this Programme[3] does not forsee any education activities related to Tourism development as well. Nevertheless creation of new tourism products with high competitiveness reguires performers with new knowledge and new skills. It means, that successful county's strategy implementation reguires well educated and high skilled human resources who are involved in implementation of county's strategy. For development knowledge, skills, and experience of people the action plan should involve activities which provide them. Creation and development of these factors build the base for qualitative and sustainable development of tourism products. Taking into account above mentioned, the following Implementation model of new Natural Tourism product is reflected in Fig.1.

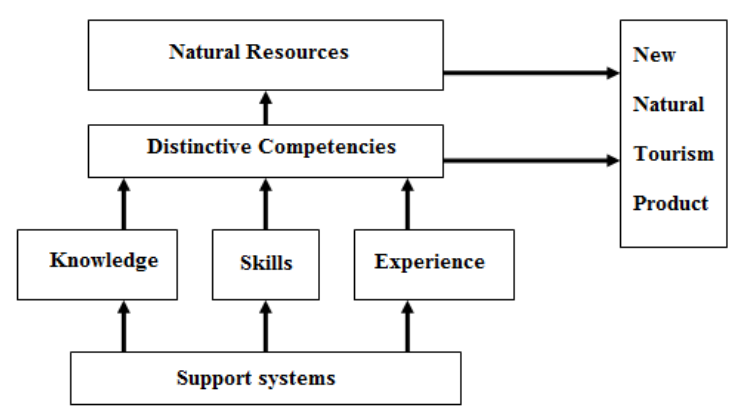

Fig.1.Implementation model of new Natural Tourism Product [15]

This model of implementation of new Natural Tourism Product [15] offered taking into account support systems which related to people, who are involved in creation of new tourism products. Support systems should provide development of knowledge, skills, and experience for these people. Support systems should ensure competitiveness and sustainability of Tourism products in total.

Related to Dagda county. Tourism education opportunities are offered in RA (50 km from Dagda) in bachelor and master level. It is necessary to strengthen cooperation between Dagda county and RA with aim to prepare high quality specialists in tourism field for Dagda county[15].

The agreement about collaboration among RA and Dagda county was signed 3 years ago. This agreement forsees cooperation in the education and research area. Dagda county is one of the rural county in Latgale. It encompasses wide-ranging of natural tourism resources as Razna National park, which includes many lakes, rivers, hills and forests, biodiversity, and ecosystems diversity. Cultural landscape roads P52, P60, P61, P57, P55 via Dagda are important tourism resources for nature tourism development. They are valuable for creation of cycle tracks. Dagda county offers unique cultural heritage, rich history of crafts and revival of crafts' traditions, etc. In accordance with spatial structure of Latgale's region, Dagda county is included in tourism development territory 'Ezerzeme'. Taking into account rich natural resources in the county one of the county's economical specialization defined in Dagda county development programme 2013.-2019 is as Nature Tourism (in the regional, state and European level). Dagda county Vision is defined as 'Dagda county is multifunctional county in Latgale region, where people are active and pleased with their life. There are well developed small businesses, processing of agriculture products with high added value, and natural tourism in this county'. Natural resources and physical cultural resources are important assets for regional competitiveness. There are close link between environmental resources and regional development Further analyses will be related to the county's specialization- Nature tourism.

The professional bachelor study programme „Enterprenership” which includes Tourism Management speciality is realized in RA. Under supervision of academical staff the students of this study programme are involvement in this collaboration process. The greatest contribution of students is their creative approach to development of sustainable tourism products. R. Florida [14] underlined, that creativity is able to become significant drive force in regional development.

The main tasks provided by RA students during their internships in Dagda county are as follows:

- to coordinate their activities related to development of new tourism products with local representatives of municipality;

- to research the notable places in Dagda county for development of hiker's routes, cycle routes, auto routes and other tourism products;

- involvement of pupils from local secondary schools in development of new tourism products;

- involvement of local inhabitents in development of new tourism products;

- to formulate a positive opinion of local inhabitents about sustainable tourism development in Dagda county;

- to work out the hiker's routes, cycle routes, and other tourism products and to approbate these new tourism products;

- to submit the concepts of new developed tourism products for approval in Dagda county Council;

- to formulate the findings of their research about the sustainable tourism development in the study works and the graduate works; 
- to inform local inhabitants about benefits of sustainable tourism development in Dagda county;

- to present their findings to local municipality Council.
The main links for partnership municipality university which takes place among Dagda county and RA are ilustrated in the tab.1. This collaboration should give the remarkable affects in short term and in long term as well.

TABLE 1.

The main links of partnership municipality - university

\begin{tabular}{|c|c|c|}
\hline Links & Short term affects & Long term affects \\
\hline $\begin{array}{l}\text { Human resources } \\
\text { training }\end{array}$ & $\begin{array}{l}\text { Training courses in tourism guides programme by } \\
\text { involvement of local population } \\
\text { Training of municipality inhabitants: Training courses in } \\
\text { development of tourism service } \\
\text { Training courses in managemenwt of sustainable } \\
\text { tourism for local authorities }\end{array}$ & $\begin{array}{l}\text { Improvement administrative capacity in tourism } \\
\text { area } \\
\text { Consulting } \\
\text { Competence development for both sides } \\
\text { Valuable and competent help in human resources } \\
\text { development }\end{array}$ \\
\hline Entrepreneurship & $\begin{array}{l}\text { Students of RA have practical placements in the } \\
\text { municipality territory. } \\
\text { Students develop innovations - new tourism products } \\
\text { Chance (for municipality) to test a potential new employee }\end{array}$ & $\begin{array}{l}\text { New work places for alumnus in the municipality: } \\
\text { High skilled specialists in tourism area will be } \\
\text { recruited. }\end{array}$ \\
\hline Research & $\begin{array}{l}\text { Students together with local people make explorations of } \\
\text { remarkable places for development of new tourists' } \\
\text { products. } \\
\text { Research of the Gastronomy and Naturer tourism } \\
\text { opportunities } \\
\text { in Dagda county } \\
\text { Students perform the Concepts of new tourism products } \\
\text { and present their at the Council of Dagda county } \\
\text { The main results are prepared and as study works or } \\
\text { graduate works are defended in RA and presented to the } \\
\text { Dagda county Council. These research works are donated } \\
\text { to Council of Dagda county. } \\
\text { Scientific publications } \\
\text { Use scientific knowledge within municipality in tourism } \\
\text { product development }\end{array}$ & $\begin{array}{l}\text { Use scientific knowledge within municipality in } \\
\text { working } \\
\text { up of tourism marketing development strategies } \\
\text { e.t.c. } \\
\text { Research posibilities for RA }\end{array}$ \\
\hline $\begin{array}{l}\text { Research } \\
\text { partnership }\end{array}$ & Exploration of particular tourism products & $\begin{array}{l}\text { Transfer scientific knowledge within municipality } \\
\text { Join projects } \\
\text { Research related activities, consulting. }\end{array}$ \\
\hline $\begin{array}{l}\text { Informal } \\
\text { interaction }\end{array}$ & $\begin{array}{l}\text { Formation of social relationships for Dagda county as the } \\
\text { tourism destination. territory. Involvement } \\
\text { population in tourism business. Involvement } \\
\text { domestic producers. } \\
\text { Meetings, seminars }\end{array}$ & $\begin{array}{l}\text { Conferences } \\
\text { Local population aware benefits from sustainable } \\
\text { tourism. They are interested in sustainable tourism } \\
\text { development and are involved in tourism business. } \\
\text { Domestic producers are involved in tourism service. }\end{array}$ \\
\hline
\end{tabular}

The new approach to collaboration municipality regional university is offered taking into account the possibilities of regional university in improvement of human resources capacity, in improvement of municipality administrative capacity, and in development of sustainable tourism products

This approach to collaboration municipality regional university in development of sustainable tourism takes into account the following aspects (Fig.2.):

- improvement and diversification of Tourism products by use students' creativity and their new view on development of tourism products;

- training and education activities related to sustainable Tourism development in county area by use capacity of the university;

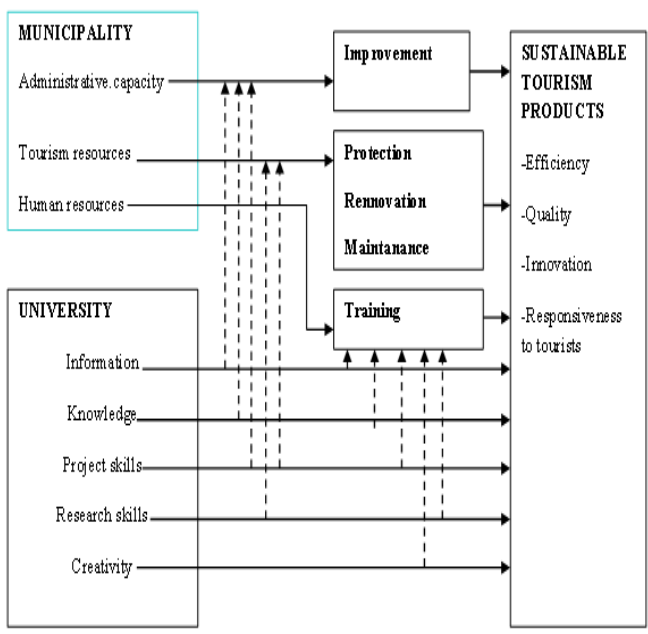

Fig.2. The model of the municipality - regional university collaboration in development of sustainable tourism 
- improvement of administrative capacity of county by use research and knowledge capacity of the university;

- improvement of county's competitiveness by Human resources management, related to people who will be involved in implementation of the Tourism Development programme;

- maintenace and protection of natural tourism resources which are the base of sustainable nature tourism products.

\section{CONCLUSION}

Regional university is significant player in regional sustainable tourism development. The forms of collaboration among regional university and municipality are different: training, research partnerships, transfer of knowledge, joint projects e.t.c. 'Universities act as an important driver of economic development and catching up through their role in education and technology absorption, adaptation, and diffusion' [16]. The author offers new approach to collaboration municipality - regional university for development sustainable tourism in regional area. This approach was formed by improvement of municipality's administrative capacity and county's human resources capacity in the field of tourism, and by protection and maintenance tourism resources. The offered approach was set up by taking into account the interests of all stakeholders in this area.

The collaboration among Dagda county and RA during three years proves by facts that it is possible to promote sustainable tourism products by use the following collaboration opportunities: training courses for people of the local municipality who are involved in tourism development activities, involvement inhabitants of the local municipality, involvement academical staff and students in development of sustainable tourism products. Regional university brings into tourism development a new creative potential.

\section{$\mathrm{V}$ ACKNOWLEDGMENTS}

This study was made feasible by thanks to Dagda county authorities, who are interested in tourism sustainable development in their county, by thanks to internship students of Rezeknes Augstskola who helped to effectively implement tourism products development activities under arrangement between Rezeknes Augstskola and Dagda city county.

\section{REFERENCES}

[1] Kamalanabhant,T., Nagaraj,I. „Impact of strategic human resource practices-on organisational performance”. Australian Journal of Psychology - Supplement p.132, 2003.

[2] Cooper,C.,Fletcher,J.,Gilbert,D.,Wanhil,S. Tourism, Principles and Practice. London: Pitman, 1998..p.458.

[3] Dagdas novada attīstības programma 2013.-2019. Available: www.dagda.lv...pdf, [Accessed: November 21,.2014]

[4] Silineviča,I. Dagdas pilsētas kā Dagdas novada centra pievilcības aspektu izpēte iedz̄ivotāju skatījumā . Latgale national Economy research..Journal of Social Sciences.Research papers,2012.- Rezekne(Latvia).pp.168.190.

[5] Strategy for cooperation with universities and colleges. Available: .http://www.linkoping.se/Global /Om\%20kommunen

Utveckling\%20och\%20samverkan/strategiska\%20universitet skontakter

/Strategi\%20samverkan_univ13_eng.pdf?epslanguage $=\mathrm{SV}$, [Accessed: December,.2014]

[6] Postma, J. The ability to work together: municipal cooperation for effective social sector policy implementation, 2013.

Available:http://essay.utwente.nl/63657/,

November,.2014]

[7] Abrahamson, E., \& Fairchild, G."Knowledge industries and idea entrepreneurs", In C. B. Schoonhoven \& E. Romanelli (Eds.),The entrepreneurship dynamic in industry evolution:147-177pp.. Stanford, CA: Stanford University.Press .2001

[8] Julian Birkinshaw, Gary Hamel,Michael J. Mol.Management Innovation. London Business School, 2008.

[9] Lennart Nilson,Mickael Planasch."Cooperation between Universities and companies/municipalities", presented at BUP Teachers' Conference St Petersburg, Russia, 2009. 2527 pp. November 2009..Available: www.balticuniv.uu.se [Accessed November 21,.2014

[10] Business and community development in Avjuvarri Indigenious Region. Available: http:www.uarctic.org/member-profiles/Norway/ 8922/ uitthe-arctic-university-of-norway. [Accessed November 24 ,2014].

[11] Commonwealth cities and international cooperation. Available: www.rezekne.lv [Accessed November 21,.2014].

[12] Project: 'Living, lived revived cultural heritage. Available:, http://www.fhs.upr.si/en/research[Accessed November $21, .2014]$.

[13] Innovative and responsible tourism territories.Available: http://www.smartplusinnovations.eu/i/IARTT [Accessed October 2,.2014]

[14] Florida, R. L. Cities and the creative class. New York:Routledge,2005.57 p.

[15] Silineviča,I Implementation problems of Development Strategies: case study of Dagda county .Integrated and Sustainable Regional Development.,2013: International scientific conference.-Jelgava(Latvia).No.31.ISSN 16913078. p.p.140-145.

[16] Yusuf,S. University-industry links: Policy dimensions. In how Universities promote Economic Growth, edited. By S.Yusuf and K. Nabeshima. 1-26. Washington DC: World Bank .Available: http://demo.netcommlabs.com/innovation grid [Accesses January 9,2015] 